\title{
Prinsip Bagi Hasil Dalam Akad Mudharabah Dan Musyarakah Pada Bank Syariah
}

\author{
Dani Ramdani \\ Program Studi Magister Kenotariatan \\ Pascasarjana Universitas Islam Bandung \\ e-mail: ramdani.dani0101@gmail.com
}

\begin{abstract}
Abstrak- Prinsip bagi hasil melalui perjanjian pembiayaan mudharabah dan musyarakah telah diatur dengan jelas oleh Undang-Undang Nomor 21 Tahun 2008 tentang Perbankan Syariah. Namun, pengguna transaksi perbankan umumnya tidak menyadari prinsipprinsip tersebut. Penelitian ini menggunakan pendekatan yuridis normatif dan menyimpulkan bahwa bagi hasil perbankan syariah yang umum digunakan adalah dana mudharabah dan musyarakah. Metode perhitungan bagi hasil dibagi menjadi tiga bagian, Pertama, pembagian laba dan rugi untuk musyarakah. Kedua, bagi hasil untuk mudharabah dan ketiga adalah bagi hasil yang digunakan untuk menghitung bagi hasil antara deposito yang menyimpan dana mereka di bank syariah.
\end{abstract}

Kata kunci: Prinsip Bagi Hasil, Mudharabah dan Musyarakah, Bank Syariah.

Abstract- The principle of profit sharing through the mudharabah and musyarakah financing agreement has been clearly regulated by the Act Number 21 of 2008 on Syariah Banking. However, people used the banking transactions generally do not aware of such principle. This paper aims to know the application of the the principle of profit sharing in mudharabah and musyarakah contract in accordance with the Act Number 21 of 2008. This research uses normative juridical approach and concluded that the commonly used profit sharing in syariah banking is mudharabah and musyarakah funding. The calculation method of profit sharing divided into three parts, First, profit and loss sharing for musyarakah. Second, profit sharing for mudharabah, and third is revenue sharing used to calculate profit sharing between depositors that keep their funding in syariah bank.

Keywords: The Principle of Profit Sharing, Mudharabah And Musyarakah, Syariah Bank.

\section{A. PENDAHULUAN}

Pembangunan ekonomi suatu Negara memerlukan program yang terencana dan terarah serta membutuhkan modal atau dana pembangunan yang tidak sedikit. Tidaklah mengherankan apabila pemerintah dalam suatu Negara terus menerus melakukan upaya peningkatan kinerja bank sebagai lembaga keuangan dan lokomotif pembangunan ekonomi. Lembaga keuangan bank yang mempunyai peranan yang strategis dalam pembangunan suatu perekonomian Negara. 
Dani Ramdani, Prinsip Bagi Hasil Dalam Akad Mudharabah Dan Musyarakah Pada Bank Syari...

\begin{abstract}
Sesuai dengan laju pertumbuhan ekonomi dan gerak pembangunan suatu bangsa, lembaga keuangan tumbuh dengan berbagai alternative jasa yang ditawarkan, lembaga keuangan yang merupakan lembaga perantara dari pihak kelebihan dana (surplus of funds) dengan pihak kekurangan dana (lack of funds)..., (Neni Sri Imaniyati,
\end{abstract} 2005:20).

Baik perbankan konvesional maupun perbankan syariah berfungsi sebagai perantara keuangan (financial intermediary) yang mempunyai sebagai pengumpul dana, penyalur dana dari dan kepada masyarakat dalam bentuk fasilitas pembiayaan selain itu berperan dalam lalu lintas pembayaran (Neni Sri Imaniyati, 2005:93). Perbankan syariah tumbuh dan dikembangkan sebagai sebuah alternative bagi praktik perbankan konvensional. Kritik terhadap bank konvensional oleh konsep perbankan syariah, bukanlah menolak bank dalam fungsinya sebagai lembaga intermediasi keuangan, melainkan dalam karekteristiknya yang lain misalnya masih terdapatnya unsur riba, judi (maysir), ketidakpastian (gharar) dan bathil (Neni Sri Ismaniyati dan Panji Adam, 2017:26).

Perbankan Syariah di Indonesia mempunyai peranan penting dalam menopang perekonomian Nasional. Peranan perbankan syariah berpegang teguh kepada Prinsip Syariah sedangkan di perbankan konvensional dengan sistem bunga (interest) yang secara syar'i bunga termasuk kepada riba dan hukumnya haram.

$$
\text { Perkembangan Perbankan }
$$
syariah di Indonesia mempunyai pijakan yang kokoh dengan lahirnya sederetan perundang-undangan yaitu Undang-Undang Perbankan Nomor 7 Tahun 1992 yang telah direvisi dengan Undang-Undang Nomor 10 Tahun 1998 kemudian terbit Undang-Undang Nomor 21 Tahun 2008 tentang Perbankan Syariah, yang merupakan dasar operasionalnya berbankan syariah yang ada di Indonesia. 
Dani Ramdani, Prinsip Bagi Hasil Dalam Akad Mudharabah Dan Musyarakah Pada Bank Syari...

Sejak saat itulah perbankan syariah yang lahir dari sistem umat Islam menjadi lebih dikenal baik oleh masyarakat muslim dan non muslim. Bahkan banyak dari perbankan konvensional pun mempunyai unit usaha khusus Bank Syariah.

Bank Syariah dengan produk utamanya yang berupa simpanan dan pembiayaan serta ditunjang dengan jasa lain-lainnya yang operasionalnya menggunakan sistem bagi hasil (syirkah).

Prinsip yang paling mendasar dari Bank Syariah adalah segala pembiayaan yang dilakukan dalam sistem perbankan terbebas dari unsur riba. Cara-cara menjauhkan dari unsur Riba (Neni

Sri Imaniyati, 2009:11) adalah:

1. Menghindari penggunaaan yang menetapkan di muka secara pasti keberhasilan suatu usaha (Q.S. Luqman ayat 34);

2. Menghindari penggunaan sistem presentasi untuk pembebanan biaya terhadap utang atau pemberian imbalan terhadap simpanan yang mengandung unsur melipatgandakan secara otomatis uang/simpanan tersebut hanya karena berjalannya waktu (Q.S. Ali Imran ayat 130);

3. Menghindari penggunaan sistem perdagangan/penyewaan barang ribawi dengan imbalan barang ribawi lainnya dengan memperoleh kelebihan baik kualitas maupun kuantitas (H. R. Muslim Bab Riba No. 1551 s.d. 1567);

4. Menghindari penggunaan sistem yang menetapkan di muka tambahan atas utang bukan atas prakarsa yang mempunyai utang secara sukarela (H. R. Muslim bab Riba No. 1569 s.d. 1572);

5. Menetapkan sistem bagi hasil dan perdagangan dengan mengacu kepada Al-Qur'an Surat Al-Baqarah ayat 275 dan Surat An-Nisa ayat 29, maka setiap transaksi kelembagaan syariah harus dilandasi atas dasar sistem bagi hasil dan perdagangan atau transaksinya didasari oleh pertukaran antara uang dengan barang, sehingga 
Dani Ramdani, Prinsip Bagi Hasil Dalam Akad Mudharabah Dan Musyarakah Pada Bank Syari...

akan mendorong produksi barang/jas, mendorong kelancaran arus barang/jasa, dapat dihindari adanya penyalahgunaan kredit, spekulasi dan inflasi.

Sistem Bagi hasil adalah suatu sistem yang meliputi tata cara pembagian hasil usaha antara penyedia dana dan pengelola dana. Pembagian hasil usaha ini dapat terjadi antara bank dan penyimpan dana ataupun antara ban dan nasabah penerima dana. Bentuk produk berdasarkan prinsip ini adalah mudharabah dan musyarakah. Lebih jauh, prinsip mudharabah dapat dipergunakan sebagai dasar, baik untuk pendanaan (tabungan dan deposito) maupun pembiayaan, sedangkan musyarakah lebih banyak untuk pembiayaan (Neni Sri Imaniyati dan Panji Adam Agus Putra, 2016:58). Dengan menggunakan prinsip bagi hasil ini baik bank syariah maupun nasabah secara bersama-sama menanggung risiko usaha dan membagi hasil usaha berdasarkan metode bagi untung dan rugi (profit and loss sharing) atau metode bagi pendapatan (revenue sharing) antara kedua belah pihak, bank syariah dan nasabahnya berdasarkan nisbah yang telah disepakati sebelumnya.

Namun pada prakteknya, masyarakat luas khususnya masyarakat yang sering melakukan transaksi perbankan kurang memahami dan bahkan tidak mengetahui apa dan bagaimana sistem bagi hasil tersebut diterapkan dalam akad mudharabah dan musyarakah dalam bank syariah.

Aplikasi dalam perbankan syariah, akad yang banyak digunakan dengan penentuan prinsip bagi hasil (syirkah atau profit sharing) adalah akad mudharabah dan akad musyarakah. Pembiayaan bagi hasil dengan akad mudharabah dan akad musyarakah memiliki perbedaan pada modal, pengelolaan usaha dan pembagian keuntungannya. Untuk itu dirumuskan masalah dalam penelitian ini yaitu bagaimana penerapan prinsip bagi hasil dalam 
Dani Ramdani, Prinsip Bagi Hasil Dalam Akad Mudharabah Dan Musyarakah Pada Bank Syari...

akad mudharabah dan

dan bahwa: "Falsafah dan etik yang

akad musyarakah dihubungkan

dengan Undang-Undang Nomor 21

Tahun 2008 tentang Perbankan

Syariah?

B. HASIL DAN PEMBAHASAN

1. Bank Syariah dan Pembiayaan pada Bank Syariah

Perkembangan Bank Syariah pada saat ini telah melaju pesat berjalan dengan munculnya Lembaga Keuangan Syariah seperti Asuransi Takaful, Pasar Modal Syariah, Pegadaian Syariah, Pegadaian Syariah, Baitul Maal wat Tamwil (BMT) bahkan Asuransi Syariah (Neni Sri Imaniyati dan Panji Adam Agus Putra, 2016:37).

Tidak hanya lembaga keuangan sebagai tersebut di atas, Koperasi pun saat ini telah banyak yang bertansformasi ke Koperasi sesuai pendapat (Neni Sri Imaniyati, 2009: 160), dalam penelitiannya berjudul Regulasi dan Eksistensi Koperasi Syariah di Kota Bandung), salah satu dalam kesimpulannya mengemukan

mendasari gerakan koperasi banyak ditemukan kesesuaian dan diberi rujukan dari segi ajaran islam, khusunya berkaitan dengan bidang ekonomi syariah, antara lain, pada penekanan akan pentingnya kerjasama dan tolong menolong (ta'awun), persaudaraan (ukhuwah), dan pandangan hidup demokrasi (musyawarah), selain dari falsafah dan nilai etik, juga dilihat dari mekanisme operasional, yakni sistem imbalan (keuntungan atau fasilitas yang dapat diterima anggota), yaitu sesuai dengan peran serta kontribusi bagi koperasi.

Menurut Undang-Undang Nomor 21 Tahun 2008 tentang Perbankan Syariah, dalam Pasal 1 angka 7, memberikan batasan pengertian Bank Syariah yaitu bank yang menjalankan kegiatan usahanya berdasarkan prinsip syariah dan menurut jenisnya terdiri atas bank umum syariah dan bank pembiayaan rakyat syariah.

Prinsip Syariah adalah prinsip yang aturan perjanjiannya atau akadnya berdasarkan hukum 
Dani Ramdani, Prinsip Bagi Hasil Dalam Akad Mudharabah Dan Musyarakah Pada Bank Syari...

Islam antara bank dengan pihak lain untuk penyimpanan dana maupun penyaluran dana. Sebagaimana dijelaskan dalam Undang-Undang Nomor 21 Tahun 2008 Pasal 4 bahwa fungsi bank syariah adalah sebagai berikut:

(1) Bank Syariah dan UUS wajib menjalankan fungsi menghimpun dan menyalurkan dana masyarakat.

(2) Bank Syariah dan UUS dapat menjalankan fungsi sosial dalam bentuk lembaga baitul maal, yaitu menerima dana yang berasal dari zakat, infak, sedekah, hibah atau dana sosial lainnya dan menyalurkannya kepada organisasi pengelola zakat.

(3) Bank Syariah dan UUS dapat menghimpun dana sosial yang berasal dari wakaf uang dan menyalurkan kepada pengelola wakaf (nazhir) sesuai dengan kehendap pemberi wakaf (wakif).

(4) Pelaksanaan fungsi sosial sebagaimana dimaksud pada ayat 2 dan ayat (3) sesuai dengan ketentuan peraturan perundang-undangan.

Pembiayaan pada Bank Syariah. Pengertian Pembiayaan menurut Undang-Undang Nomor 10 Tahun 1998 tentang Perbankan Pasal 1 angka 12 bahwa Pembiayaan adalah penyediaan uang atau tagihan yang dipersamakan dengan itu berdasarkan persetujuan atau kesepakatan antara bank dengan pihak lain yang mewajibkan pihak yang dibiayai untuk mengembalikan uang atau tagihan tersebut setelah jangka waktu tertentu dengan imbalan atau bagi hasil.

Pembiayaan menurut Pasal 1 angka 25 Undang-Undang Nomor 21 Tahun 2008 bahwa Pembiayaan adalah penyediaan dana atau tagihan yang dipersamakan untuk itu berupa:

a. Transaksi bagi hasil dalam bentuk mudharabah dan musyarakah;

b. Transaksi sewa-menyewa dalam bentuk ijarah atau sewa beli dalam bentuk ijarah muntahiya bittamlik; 
Dani Ramdani, Prinsip Bagi Hasil Dalam Akad Mudharabah Dan Musyarakah Pada Bank Syari...

c. Transaksi jual beli dalam bentuk piutang murabahah, salam dan istishna;

d. Transaksi pinjam meminjam dalam bentuk piutang qardh;

e. Transaksi sewa-menyewa jasa dalam bentuk ijarah untuk transaksi multijasa berdasarkan persetujuan atau kesepakatan antara bank syariah dan/atau UUS dan pihak lain yang mewajibkan pihak dibiayai dan/atau di fasilitasi dana untuk mengembalikan dana tersebut setelah jangka waktu tertentu dengan imbalan ujrah, tanpa imbalan atau bagi hasil.

Pembiayaan menurut sifat penggunaan dibagi menjadi dua bagian. Pertama, pembiayaan produktif yaitu pembiayaan yang ditujukan untuk memenuhi kebutuhan produksi dalam arti luas. Kedua, pembiayaan konsumtif yaitu pembiayaan yang digunakan untuk memenuhi kebutuhan konsumsi. Sedangkan menurut keperluannya pembiayaan produktif dibagi menjadi dua, pertama pembiayaan modal kerja yiatu pembiayaan untuk memenuhi kebutuhan peningkatan produksi baik secara kuantitatif maupun kualitatif. Kedua, untuk keperluannya perdagangan atau peningkatan utility of place dari suatu barang.

Berbicara masalah produk pembiayaan tidak terlepas dengan proses transaksi yang dinamakan dengan akad ('aqd) jamaknya aluqud. Oleh karena itu al-uqd ini menjadi salah satu persoalan pokok yang mutlak penting untuk diperhatikan (Neni Sri Imaniyati dan Panji Adam Agus Putra, 2006: 53).

Pengertian Akad, secara Bahasa artinya ikatan, mengencangkan, menjamin atau perjanjian. Menurut istilah akad adalah sesuatu yang menjadi komitmen seseorang yang menuntut agar orang lain melakukan suatu perbuatan tertentu yang dia inginkan. Secara khusus, akad adalah ikatan antara beberapa pihak transaksi melalui ijab dan qabul (Sandi Rizki Febriadi, 2018).

Menurut Kompilasi Ekonomi Syariah dalam angka 1, Aqad 
Dani Ramdani, Prinsip Bagi Hasil Dalam Akad Mudharabah Dan Musyarakah Pada Bank Syari...

adalah kesepakatan dalam suatu perjanjian antara dua pihak atau lebih untuk melakukan dan atau tidak melakukan perbuatan hukum tertentu.

Dalam Pasal 1 angka 13 Undang-Undang Nomor 21 Tahun 2008 tentang Perbankan Syariah (selanjutnya disebut UUPS) menegaskan pengertian aqad, adalah kesepakatan tertulis antara bank syariah atau Unit Usaha Syariah (UUS) dan pihak lain yang memuat adanya hak dan kewajiban bagi masing-masing pihak sesuai dengan prinsip syariah.

Menurut (Habib Adjie dan Muhammad Hafidh, 2017:24), Akad sebagai kesepakatan tertulis dituangkan dalam bentuk akta notaris ataupun di bawah tangan. Sudah menjadi kebiasaan dalam praktik perbankan dan praktik bisnis lainnya, dalam memberikan fasilitas kepada para pengguna jasa atau nasabah, hubungan hukum antara bank dan para nasabah selalu dituangkan dalam perjanjian tertulis. Karena hubungan hukum antara bank

dan nasabahnya dituangkan dalam suatu perjanjian maka berlaku ketentuan-ketentuan dan syaratsyarat yang dituangkan dalam perjanjian itu (Neni Sri Imaniyati, 2002:77).

Menurut Neni Sri Imaniyati dan Panji Adam, 2017: 46, mengemukan bahwa definisi akad terdapat 3 (tiga) poin penting yang harus diperhatikan dalam akad. Pertama, akad merupakan pertemuan/pertalian antara ijab dan Kabul yang menimbulkan akibat hukum. Ijab adalah penawaran yang diajukan oleh salah satu pihak, dan Kabul adalah jawaban persetujuan yang dinyatakan pihak lain sebagai tanggapan terhadap penawaran pihak pertama. Kedua, akad merupakan tindakan hukum dua pihak karena akad adalah pertemuan ijab yang mewakili kehendak satu pihak dan Kabul yang menyatakan kehendak pihak lain. Ketiga, tujuan akad adalah untuk melahirkan suatu akibat hukum.

Menurut

berdasarkan batasan-batasan pengertian akad tersebut di atas 
Dani Ramdani, Prinsip Bagi Hasil Dalam Akad Mudharabah Dan Musyarakah Pada Bank Syari...

dapat disimpulkan pengertian akad. Akad, adalah perjanjian atau permufakatan antara dua orang atau lebih dalam melakukan suatu perbuatan hukum tertentu didasarkan prinsip-prinsip yang dibenarkan oleh syara', yang dibuat dan dicatat dalam bentuk akta notaris maupun di bawah tangan.

Dasar Hukum Akad sebagaimana dijelaskan dalam QS. Al-Maidah (5): 1 dan An-Nahl (16): 91 serta hadis-hadis menjelaskan bahwa setiap akadakad tersebut harus dipenuhi.

Rukun Akad (Sandi Rizki Febriadi, 2018) adalah adanya pihak yang melakukan akad, shighah (pernyataan ijab dan qobul) dan ma'qud alaih (objeknya tertentu).

Sandi Rizki Febriadi, 2017 dalam Pelatihan Dasar Perbankan Syariah yang dilaksanakan di Pascasarjana Universitas Silam Bandung, mengemukakan syaratsyarat akad adalah sebagai berikut:

a. Syarat Terjadi Akad (syuruth al-in'iqad). Termasuk syarat umur yaitu rukum yang harus ada pada setiap akad,seperti orang berakad, objek akad, sighah. Yang dimaksud syarat khusus ialah syarat-syarat yang harus ada pada sebagian akad dan tidak diisyaratkan pada bagian lainnya seperti syarat harus adanya saksi (aqd aljawaz) dan keharusan penyerahan barang/objek akad pada al'uqud al-ainiyyah.

b. Syarat sahnya akad (syuruth as-shihah). Menurut ulama Hanafiah syarat sahnya akad, apabila terhindar dari: $A l$ jahalah, al-ikrah, attauqi, al-gharar dan al-syarfu al-fasid (syarat-syarat rusak, seperti pemberian syarat terhadap pembeli untuk menjual kembali barang dibelinya tersebut kepada penjual dengan harga yang lebih murah).

c. Syarat Pelaksanaan Akad (syuruth an-nafidz). Syarat ini bermaksud berlangsungnya akad tidak tergantung pada izin orang lain. Syarat berlakunya suatu akad yaitu (1). Adanya kepemilikan terhadap barang atau adanya otoritas (al- 
Dani Ramdani, Prinsip Bagi Hasil Dalam Akad Mudharabah Dan Musyarakah Pada Bank Syari...

wilayah) untuk mengadakan akad baik secara langsung ataupun perwakilan. (2). Pada barang atau jasa tersebut tidak terhadap hak orang lain.

d. Syarat kepastian hukum atau kekuatan hukum (syuruth aliltizam). Suatu akad baru mempunyai kekuatan mengikat apabila ia terbatas dari segala macam hak khiyar. Khiyar adalah hak pilih bagi penjual dan pembeli untuk melanjutkan atau membatalkan akad jual beli yang dilakukan.

Ada beberapa asas akad yang harus dilindungi dan dijamin oleh UUPS (Neni Sri Imaniyati dan Panji Adam Agus Putra, 2016: 53), asas-asas tersebut sebagai berikut:

a. Asas Ridha'iyyah (Rela Sama Rela);

Maksud asas ini adalah bahwa transaksi ekonomi dalam bentuk apapun dilakukan perbankan dengan pihak lain terutama nasabah harus didasarkan atas prinsip rela sama rela bukan suka sama suka,yang bersifat hakiki. Asas ini didasarkan pada sejumlah ayat Al-Qur'an dan Al-Hadist, terutama QS. An-Nisa (4):29. Atas dasar asas 'an-taradhin/ al-taradhi, semua bentuk transaksi yang mengandung unsur paksaan (ikrah) harus di tolak dan dinyatakan batal demi hukum. Itu sebabnya mengapa Islam mengharamkan bentuk transaksi ekonomi apapun yang mengandung unsur kebatilan (al-bathil), misalnya jual beli yang mengandung unsur pemaksaan (bay'ul mukrah),

b. Asas Manfaat;

Asas manfaat maksudnya ialah bahwa akad yang dilakukan oleh bank dengan nasabah berkenaan dengan halhal (objek) yang bermanfaat bagi kedua belah pihak. Itulah sebabnya mengapa Islam mengharamkan akad yang berkenaan dengan hal-hal yang bersifat mudharat/mafsadat seperti jual beli benda-benda yang diharamkan dan/atau benda-benda yang tidak bermanfaat apalagi membahayakan.

c. Asas Keadilan; 
Dani Ramdani, Prinsip Bagi Hasil Dalam Akad Mudharabah Dan Musyarakah Pada Bank Syari...

Asas keadilan dalam arti kedua belah pihak yang melakukan transaksi ekonomi (bank dan nasabah) harus berlaku dan diberlakukan secara adil dalam konteks pengertian yang luas dan konkret. Hal ini didasarkan pada sejumlah ayat Al-Qur'an yang sangat menjunjung tinggi keadilan dan antikezaliman. Termasuk dalam hal ekonomi yang disimbolkan dengan bentuk riba sebagaimana dalam QS.AlHadid : 57.

d. Asas Menguntungkan;

$$
\text { Asas }
$$
saling menguntungkan maksudnya, setiap akad yang dilakukan oleh pihak yang berakad. Tidak boleh menguntungkan satu pihak dengan merugikan pihak lain. Itulah sebabnya mengapa Islam mengharamkan jual beli (perdagangan) yang mengandung unsur gharar (penipuan) karena hanya menguntungkan satu pihak dengan merugikan pihak lain. Demikian pula dengan praktik perjudian yang hanya menguntungkan segelintir orang dengan merugikan banyak pihak, bahkan masyarakat luas.

Dengan memperhatikan uraian tersebut di atas bahwa suatu akad sangat menentukan suatu perbuatan hukum atau pembiayaan dapat menjadi halal ketika terpenuhi semua rukun dan syaratsyarat akad sedangkan jika tidak terpenuhi menyebabkan fasid bahkan hukumnya menjadi haram. Selaras dengan tujuan pembiayaan berdasarkan prinsip syariah adalah untuk meningkatkan kesempatan kerja dan kesejahteraan ekonomi sesuai dengan nilai-nilai Islam. Pembiayaan tersebut harus dapat dinikmati oleh sebanyakbanyaknya pengusaha yang bergerak dibidang industri, pertanian, dan perdagangan untuk menunjang kesempatan kerja dan menunjang produksi dan distribusi barang-barang dan jasa-jasa dalam memenuhi kebutuhan dalam negeri yang terlepas dari unsur ribawi.

\section{Karakteristik Bank Syariah}

Bank Syariah adalah bank umum yang melaksanakan kegiatan usaha berdasarkan prinsip 
Dani Ramdani, Prinsip Bagi Hasil Dalam Akad Mudharabah Dan Musyarakah Pada Bank Syari...

syariah yang dalam kegiatannya memberikan jasa dalam lalu lintas pembayaran,dalam menjalankan aktivitasnya menganut prinsipprinsip sebagai berikut:

Prinsip Keadilan, bahwa dengan system operasional yang berdasarkan profit and loss sharing system merupakan karakteristik yang fundamental berbeda dari system konvesional yang didalam terkandung dimensi keadilan dan pemerataan.

Prinsip Kesederajatan, menempatkan nasabah penyimpan dana maupun bank pada kedudukan yang sama dan sederajat. Hal ini tercermin dalam hak, kewajiban, risiko dan keuntungan yang berimbang antara nasabah penyimpan dana, nasabah pengguna dana maupun bank. Dengan sistem bagi hasil adanya kemitraan yang sama-sama menanggung kerugian dan keuntungan.

Prinsip Ketentraman, bahwa aktivitas dan kegiatan ekonomi dalam persfektif islam untuk mencapai falah (ketentraman, kesejateraan, atau kebahagian).
Untuk pencapaian falah tersebut dalam kegiatan ekonomi harus terlepas dari unsur riba, terhindar dari aktivitas yang melibatkan spekulasi (gharar), penerapan zakat harta, dan tidak memproduksi produk-produk atau jasa yang bertentangan dengan nilai Islam.

\section{AKAD MUDHARABAH}

\section{a. Definisi Mudharabah}

Mudharabah berasal dari kata dharb artinya memukul atau berjalan. Pengertian memukul atau berjalan ini lebih tepatnya adalah proses seseorang menggerakkan kakinya menjalankan usahanya..., (Panji Adam, 2017:93).

Mudharabah adalah akad kerja antara bank dengan nasabah. Bank sebagai dengan nama shohibul mal memberikan dana $100 \%$ kepada mudharib yang memiliki keahlian

(Neni Sri Imaniyati, 2013:104).

Menurut Pasal 1 angka 5 Peraturan Bank Indonesia Nomor : 7/46/PBI/2005 bahwa yang dimaksud dengan Mudharabah adalah penanaman dana dari pemilik dana (shahibul maal) 
Dani Ramdani, Prinsip Bagi Hasil Dalam Akad Mudharabah Dan Musyarakah Pada Bank Syari...

kepada pengelola dana (mudharib) untuk melakukan kegiatan usaha tertentu dengan pembagian menggunakan metode bagi untung dan rugi (profit and loss haring) atau metode bagi pendapatan (revenue sharing) antara kedua belah pihak berdasarkan nisbah yang telah disepakati sebelumnya.

Menurut Pasal 19 ayat 1 huruf c UUPS bahwa Akad Mudharabah dalam pembiayaan adalah akad kerja sama suatu usaha antara pihak pertama (malik, shahibul mal atau bank syariah) yang menyediakan seluruh modal dan pihak kedua ('amil mudharib atau nasabah) yang bertindak selaku pengelola dengan membagi keuntungan usaha sesuai dengan kesepakatan yang dituangkan dalam dalam akad, sedangkan kerugian ditanggung sepenuhnya oleh bank syariah, kecuali jika pihak kedua melakukan kesalahan yang disengaja, lalai atau menyalahi perjanjian. Jadi pembiayaan mudharabah merupakan transaksi investasi yang bersifat investasi dalam rangka penyediaan modal usaha untuk jangka waktu tertentu sesuai dengan kesepakatan bersama antara bank dan nasabah. Mudharabah merupakan pencampuran modal dengan jasa (keterampialn atau keahlian). Keuntungan dibagi berdasarkan nisbah (porsi bagi hasil dalam persentase) yang telah disepakati. Kerugian ditanggung oleh penyandang modal (shahibul maal), sedangkan yang mengontribusikan jasanya kehilangan waktu dan peluang finansial (Ikatan Bankir Indonesia, 2018: 35).

\section{b. Landasan yuridis}

Menurut Panji Adam, 2017: 97-103 bahwa sumber-sumber Akad Mudharabah adalah sebagai berikut:

1) Al-Qur'an

a) Surat Al-Maidah ayat 1 "Hai orang yang beriman! Penuhilah akad-akad itu".

b) Surat An-Nisa ayat 29

"Hai orang yang beriman! Janganlah kalian saling memakan (mengambil) harta 
Dani Ramdani, Prinsip Bagi Hasil Dalam Akad Mudharabah Dan Musyarakah Pada Bank Syari...

sesamamu dengan jalan yang batil, kecuali dengan jalan perniagaan yang berlaku sukarela diantaramu".

c) Al-Baqarah ayat 283

"Maka, jika sebagian kamu mempercayai sebagian yang lain, hendaklah yang dipercayai itu menunaikan amanatnya dan hendaknya ia bertakwa kepada Tuhannya".

2) Al-Hadits

a) Riwayat AlThabrani,Baihaqi dan AlDaruquthni, Rasulullah SAW, bersabda:

"Apabila ia menyerahkan sejumlah harta dalam investasi mudharabah, maka ia membuat syarat kepada mudharib, agar harta itu tidak dibawa melewati lautan, tidak menuruni lembah dan tidak diberikan kepada binatang, jika mudharib melanggar syaratsyarat tersebut, maka ia bertanggungjawab menanggung risiko. Syaratsyarat yang diajukan Abbas tersebut sampai kepada Rasulullah SAW., lalu Rasul membenarkannya (mengizinkannya)".

b) Riwayat Ibnu Majah dari Shuhaib, Nabi SAWA bersabda:

"Ada tiga hal yang mengandung berkah: jual beli tidak secara tunai, muqaradhah (mudharabah) dan mencampur gandum tepung untuk di konsumsi keperluan rumah tangga,bukan untuk dijual".

3) Ijma

Kesepakatan para ulama mengenai boleh mudharabah dikutip dari Dr.Wahbah AlZuhli: "diriwayatkan bahwa sejumlah sahabat melakukan mudharabah dengan menggunakan harta anak yatim sebagai modal dan tidak ada seorang pun dari mereka (para sahabat) yang menyanggahnya ataupun menolaknya dan otomatis hal tersebut menjadi sebuah konsensus".

Jika praktik sahabat dalam suatu amalan tertentu disaksikan 
Dani Ramdani, Prinsip Bagi Hasil Dalam Akad Mudharabah Dan Musyarakah Pada Bank Syari...

oleh para sahabat lain dan tidak ada seorangpun yang menyanggahnya, maka hal itu merupakan ijma.

Landasan Pembiayaan Mudharabah dalam Fatwa DSN MUI Nomor: 07/DSNMUI/IV/2000 (Andri Soemitra, 2016: 76) Fitur dan mekanisme Akad Pembiayaan Mudharabah adalah:

1) Bank bertindak sebagai pemilik dana (shahibul maal) yang menyediakan dana dengan fungsi sebagai modal kerja dan nasabah sebagai pengelola dana (mudharib) dalam kegiatan usahanya.

2) Bank memiliki hak dalam pengawasan dan pembinaan usaha nasabah walaupun tidak ikut serta dalam pengelolaan usaha nasabah, antara lain bank dapat melakukan review dan meminta bukti-bukti dari laporan hasil usaha nasabah berdasarkan bukti pendukung yang dapat dipertanggungjawabkan.
3) Pembagian hasil usaha dari pengelolaan dana dinyatakan dalam nisbah yang disepakati.

4) Nisbah bagi hasil yang disepakati tidak diubah sepanjang waktu investasi, kecuali atas dasar kesepakatan para pihak.

5) Jangka waktu pembiayaan atas dasar akad mudharabah, pengembalian dana dan pembagian hasil usaha ditentukan berdasarkan kesepakatan bank dan nasabah.

6) Pembiayaan atas dasar akad mudharabah diberikan dalam bentuk uang dan/atau barang, serta bukan dalam bentuk piutang atau tagihan,

7) Dalam hal pembiayaan aas dasar akad mudharabah diberikan dalam bentuk uang harus dinyatakan secara jelas jumlahnya.

8) Pembiayaan atas dasar akad mudharabah diberikan dalam bentuk barang, maka barang tersebut dinilai atas dasar harga pasar (net realizable value) dan dinyatakan secara jelas jumlahnya. 
Dani Ramdani, Prinsip Bagi Hasil Dalam Akad Mudharabah Dan Musyarakah Pada Bank Syari...

9) Pengembalian pembiayaan atas dasar mudharabah dilakukan dengan dua cara yaitu secara angsuran ataupun sekaligus pada akhir periode, sesuai dengan jangka waktu pembiayaan atas dasar akad mudharabah.

10) Pembagian hasil usaha dilakukan atas dasar laporan hasil usaha pengelola dana (mudharib) dengan disertai bukti pendukung yang dapat dipertanggungjawabkan.

11) Kegiatan Usaha nasabah mengelola dana (mudharib) yang ditanggung oleh bank selaku pemilik dana (shahibul mal) adalah maksimal sebesar jumlah pembiayaan yang diberikan ( $r a$ 'sul mal).

\section{c. Rukun dan Syarat}

\section{Mudharabah}

Rukun Mudharabah adalah

1) Shahib al-mal (pemilik modal);

2) Mudharib (pengelola); 3) Shighat (ijab dan qobul); 4) $R a$ 's al-mal (modal); 5) Pekerjaan dan keuntungan (Panji Adam, 2017: 107).

Syarat-syarat akad pembiayaan mudharabah (Panji Adam, 2017: 107) adalah:

1) Pemodal dan Pengelola

a) Pemodal dan pengelola harus mampu melakukan transaksi dan sah secara hukum.

b) Keduanya harus mampu bertindak sebagai wakil dan kafil dari masing-masing pihak.

c) Shigat yang dilakukan bisa secara eksplisit dan implisit yang menunjukkan tujuan akad.

d) Sah sesuai dengan syaratsyarat yang diajukan dalam penawaran dan akad bisa dilakukan secara lisan atau verbal, secara tertulis ataupun ditandatangani.

\section{2) Modal}

a) Dinyatakan dengan jelas jumlah dan jenisnya, yaitu mata uang. Apabila modal dalam bentuk barang maka barang tersebut harus dihargakan dengan harga 
Dani Ramdani, Prinsip Bagi Hasil Dalam Akad Mudharabah Dan Musyarakah Pada Bank Syari...

semasa mata uang yang beredar (atau sejenisnya).

b) Harus berbentuk tunai bukan piutang (namun sebagian ulama membolehkan modal mudharabah berbentuk aset perdagangan, misalnya inventory).

c) Harus diserahkan kepada mudharib untuk mungkin melakukan usaha.

3) Keuntungan

a) Keuntungan harus dibagi untuk kedua belah pihak,

b) Pembagian keuntungan harus dinyatakan dalam persentase keuntungan yang mungkin dihasilkannya nanti.

c) Rasio persentase (nisbah) harus dicapai melalui negoisasi dan dituangkan dalam kontrak.

d) Waktu pembagian keuntungan dilakukan setelah mudharib mengembalikan seluruh (atau sebagian) modal kepada shahibul mal.

e) Jika jangka waktu akad mudharabah relatif lama, maka nisbah keuntungan dapat disepakati untuk ditinjau dari waktu ke waktu.

f) Jika penentuan keuntungan dihitung berdasarkan keuntungan kotor (gross profit), biaya-biaya yang timbul disepakati oleh kedua belah pihak karena dapat mempengaruhi nilai keuntungan.

4) Pekerjaan

Pekerjaan/usaha

perniagaan adalah kontribusi mudharib dalam kontrak mudharabah yang disediakan sebagai pengganti untuk modal yang disediakan oleh shahib almal. Dalam konteks ini, pekerjaan berhubungan dengan manajemen kontrak mudharabah. Syarat yang harus dipenuhi adalah usaha perniagaan adalah hak eklusif mudharib tanpa adanya interpensi dari pihak shahib almal. Walaupun Mazhab Hambali, shahibul maal boleh memberikan kontribusi dalam pekerjaan tersebut.

\section{d. Jenis-jenis Mudharabah}


Dani Ramdani, Prinsip Bagi Hasil Dalam Akad Mudharabah Dan Musyarakah Pada Bank Syari...

Mudharabah terbagi menjadi dua bagian; pertama, mudharabah mutlaqah (investasi tidak terikat), yaitu mudharabah, yang jangkuannya luas. Transaksi ini tidak dibatasi oleh spesifikasi jenis usaha, waktu dan wilayah bisnis. Shahibul mal memberikan keleluasaan kepada mudharib untuk melakukan usaha sesuai kehendaknya tetapi sejalan dengan prinsip syariah, dengan modal yang diberikan kepadanya. Kedua, mudharabah muqayyaddah yaitu kebalikan dari jenis yang pertama. Dalam mudharabah jenis ini, mudharib terikat oleh persyaratan yang diberikan oleh shahibul mal didalam meniagakan modal yang dipercayakan kepadanya. Persyaratan ini dapat berupa jenis usaha, tenggang waktu melakukan usaha dan wilayah niaga (Mardani, 2014: 140).

Mudharabah yang tidak terbatas, mudharib harus diberikan perintah dan wewenang melakukan hal-hal yang diperlukan dalam melakukan usaha. Seluruh pengeluaran rutin yang berhubungan dengan niaga, yang bukan pengeluaran pribadi mudharib akan dibebankan ke dalam akun mudharabah. Mudharib tidak diperbolehkan untuk melakukan perhitungan ulang atau menentukan angka mutlak terhadap keuntungan di muka, keuntungan dibagi antara shahibul mal dan mudharib sesuai dengan proposi yang telah ditentukan secara jelas dalam akad mudharabah. Semua pembagian laba yang dibagikan sebelum adanya keputusan final tentang perjanjian mudharabah akan dianggap sebagai sesuatu yang ditentukan di muka. Segala kerugian yang terjadi karena risiko bisnis harus dibebankan terhadap keuntungan sebelum dibebankan terhadap modal yang dimiliki oleh shahibul mal. Prinsip umum adalah shahibul mal hanya menanggung risiko modalnya, sementara risiko mudharib hanyalah usaha dan waktunya. Itu sebabnya mengapa mudharabah mutlaqah merupakan mudharabah yang saling menguntungkan. 
Dani Ramdani, Prinsip Bagi Hasil Dalam Akad Mudharabah Dan Musyarakah Pada Bank Syari...

Mudharabah muqayyadah, mudharib dalam menjalankan usaha atau perniagaan tidak boleh melebihi modal yang disetorkan oleh shahibul mal. Kewajiban shahibul sebagai partner pasif Jika atas kehendak mudharib maka keuntungan dan kerugiannya ditanggung atau menjadi risiko mudharib sendiri. Apabila mudharib yang memiliki modal dengan jumlah tertentu dalam akad mudharabah, maka dia akan menerima seluruh keuntungan sesuai dengan porsinya sebagaimana yang telah disepakati.

\section{e. Aplikasi Mudharah Dalam}

\section{Bank Syariah.}

Mudharabah, biasanya diterapkan pada produk-produk pembiayaan dan pendanaan. Pada sisi penghimpunan dana, (Antonio, 2003:97), mudharabah diterapkan pada 1) tabungan berjangka, yaitu tabungan yang dimaksudkan untuk tujuan khusus seperti tabungan haji, tabungan kurban,dan sebagainya. 2) Deposito biasa dan deposito special (special investment) dimana dana yang dititipkan nasabah khusus untuk bisnis tertentu misalnya murabahah saja atau ijarah saja. Sedangkan pada sisi pembiayaan mudharabah diterapkan pada 1) pembiayaan modal kerja, seperti modal kerja perdagangan dan jasa; 2) investasi khusus disebut juga mudharabah muqayyadah, dimana sumber dana khusus dengan penyaluran yang khusus dengan syarat-syarat yang telah ditetapkan oleh shahibul maal.

\section{Akad Musyarakah}

\section{a. Definisi Musyarakah}

Secara etimologis, musyarakah adalah penggabungan, percampuran, atau serikat. Musyarakah berarti kerjasama kemitraan atau dalam Bahasa Inggris disebut Partnership. Adapun seara terminologis, musyarakah adalah kerja sama usaha antara dua pihak atau lebih untuk suatu usaha tertentu, dimana masing-masing pihak memberikan kontribusi dengan kesepakatan bahwa keuntungan dan risiko akan ditanggung bersama sesuai dengan kesepakatan (Mardani, 2014: 142). 
Dani Ramdani, Prinsip Bagi Hasil Dalam Akad Mudharabah Dan Musyarakah Pada Bank Syari...

Menurut Penjelasan Pasal 19 ayat (1) huruf c Undang-Undang Nomor 21 Tahun 2008 tentang Perbankan Syariah, musyarakah adalah yaitu akad kerjasama di antara dua pihak atau lebih untuk suatu usaha tertentu yang masingmasing pihak memberikan porsi dana dengan ketentuan akan dibagi sesuai kesepakatan bahwa keuntungan dan risiko akan ditanggung bersama sesuai dengan kesepakatan.

\section{b. Landasan Yuridis}

Menurut Antonio, 2013 : 90 bahwa Musyarakah disyariatkan dalam:

1) Al-Qur'an Surat An-Nisa : 12 artinya: “...Maka mereka berserikat pada sepertiga..." dalam Surat As-Shaad: 24 artinya: "Dan, sesungguhnya kebanyakan dari orang-orang yang berserikat itu sebagian mereka berbuat zalim kepada sebagian yang lain kecuali orang yang beriman dan mengerjakan amal shaleh."

Kedua ayat tersebut di atas menunjukkan perkenan dan pengakuan Allah SWT akan adanya perserikatan dalam kepemilikan harta. Hanya saja dalam surat An-Nisa:12 perkongsian terjadi secara otomatis karena waris sedangkan dalam Surat Shaad:24 terjadi atas dasar akad.

2) Al-hadits, diriwayatkan Abu Dawud:

Rasulullah SAW, bersabda "Sesungguhnya Allah Azza wa Jalla berfirman, Aku pihak ketiga dari dua orang yang berserikat selama salah satu tidak menghianati lainnya."

Hadits qudsi tersebut menunjukkan kecintaan Allah kepada hamba-hamba Nya yang melakukan perkongsian selama saling menjunjung tinggi amanat kebersamaan dan menjauhi pengkhiatan.

3) Ijma, Ibnu Qudamah dalam kitabnya al-mughni, telah berkata: "Kaum muslimin telah berkonsensus terhadap legitimasi musyarakah secara global walaupun terdapat 
Dani Ramdani, Prinsip Bagi Hasil Dalam Akad Mudharabah Dan Musyarakah Pada Bank Syari...

perbedaan pendapat dalam beberapa elemen darinya".

Landasan Akad Musyarakah dalam Fatwa DSN Nomor: 08/DSN-MUI/IV/2000, fitur dan mekanisme akad pembiayaan musyarakah dalam fatwa tersebut adalah:

1) Bank dan nasabah masingmasing bertindak sebagai mitra usaha bersama-sama menyediakan dana dan/atau barang untuk membiayai suatu kegiatan usaha tertentu,

2) Nasabah bertindak sebagai pengelola usaha dan bank sebagai mitra usaha dapat ikut serta dalam pengelolaan usaha sesuai dengan tugas dan wewenang yang disepakati seperti melakukan review dan meminta bukti-bukti dari laporan hasil usaha nasabah berdasarkan bukti pendukung yang dapat dipertanggungjawabkan.

3) Pembagian hasil usaha dari pengelolaan dana dinyatakan dalam nisbah,

4) Nisbah bagi hasil yang disepakati tidak dapat diubah sepanjang jangka waktu investasi kecuali atas dasar kesepakatan para pihak,

5) Pembiayaan atas dasar akad musyarakah diberikan dalam bentuk uang dan/atau barang, bukan dalam bentuk piutang atau tagihan.

6) Dalam hal pembiayaan atas dasar akad musyarakah diberikan dalam bentuk uang harus dinyatakan secara jelas jumlahnya.

7) Dalam hal pembiayaan atas dasar akad musyarakah diberikan dalam bentuk barang, maka barang tersebut harus dinilai atas dasar harga pasar dan dinyatakan secara jelas jumlahnya.

8) Jangka waktu pembiayaan atas dasar akad musyarakah pengembalian dana dan pengembalian hasil usaha ditentukan berdasarkan kesepakatan antara bank dan nasabah.

9) Pengembalian pembiayaan atas dasar akad musyarakah dilakukan dalam dua cara, yaitu secara angsuran ataupun 
Dani Ramdani, Prinsip Bagi Hasil Dalam Akad Mudharabah Dan Musyarakah Pada Bank Syari...

sekaligus pada akhir periode akhir, sesuai dengan jangka waktu pembiayaan atas dasar akad musyarakah.

10) Pembagian hasil usaha berdasarkan laporan hasil usaha pengelola nasabah dengan disertai bukti pendukung yang dapat dipertanggungjawabkan.

11) Bank dan nasabah dapat menanggung kerugian secara proposional menurut porsi modal masing-masing.

\section{c. Rukun dan Syarat}

\section{Musyarakah}

Rukun musyarakah terdiri dari : ijab qobul, pihak bertransaksi, dan objek transaksi (Panji Adam, 2017:144).

Syarat-syarat musyarakah adalah adanya akad, keuntungan dikualifikasikan, dan penentuan pembagian hasil tidak bisa disebutkan dalam jumlah nomimal yang pasti

(Panji Adam, 2017:144).

\section{d. Jenis-Jenis Akad Musyarakah}

Menurut Antonio, 2003: 91 bahwa jenis akad musyarakah dibagi menjadi: syirkah al milk, kepemilikan dua atau lebih dari suatu property dan syirkah akad, kemitraan terjadi karena kontrak bersama.

Syirkah akad dibagi menjadi empat bagian yaitu Syirkah alamwal, Syirkah al-mufawadhah, syirkah al-a'mal dan syirkah alwujuh.

\section{e. Aplikasi Akad Musyarakah dalam Bank Syariah}

Musyarakah, diterapkan dalam bank syariah adalah melalui, Pertama, Pembiayaan proyek, dimana nasabah dan bank samasama menyediakan dana untuk membiayai proyek tersebut. Setelah proyek itu selesai, nasabah mengembalikan dana tersebut bersama bagi hasil yang telah disepakati untuk bank. Kedua, Modal Ventura, investasi dalam kepemilikan perusahaan, al-musyarakah diterapkan dalam skema modal ventura penanaman modal dilakukan jangka waktu tertentu dan setelah bank melakukan divestasi atau menjual sebagian sahamnya baik secara singkat maupun bertahap. (Antonio, 2003:93). 
Dani Ramdani, Prinsip Bagi Hasil Dalam Akad Mudharabah Dan Musyarakah Pada Bank Syari...

\section{Manfaat Akad Mudharabah dan Musyarakah}

Setiap pembiayaan dalam prinsip syariah dapat diambil hikmah atau manfaat bagi bank maupun nasabah (Antonio, 2003:97) adalah: Bank akan menikmati peningkatan bagi hasil pada saat keuntungan usaha nasabah meningkat, Bank tidak berkewajiban bagi hasil kepada nasabah pendanaan secara tetap, tetapi disesuaikan dengan pendapatan/hasil usaha bank sehingga bank tidak akan pernah mengalami negative spread, Pengembalian pokok pembiayaan disesuaikan dengan chash flow/arus kas usaha nasabah sehingga tidak membebatkan nasabah, Bank akan lebih efektif dan hati-hati (prudent) mencari usaha yang benar-benar halal, aman, dan menguntungkan karena keuntungan yang konkret dan benar-benar terjadi itulah yang dibagikan, Prinsip bagi hasil dalam mudharabah ini berbeda dengan prinsip bunga tetap dimana bank akan menagih penerimaan pembiayaan (nasabah) satu jumlah bunga tetap berapa pun keuntungan yang dihasilkan nasabah, sekalipun merugi dan terjadi krisis ekonomi.

\section{Risiko Pembiayaan Akad} Mudharabah

dan

\section{Musyarakah}

Analisis dan identifikasi risiko dalam akad mudharabah maupun musyarakah dipengaruhi beberapa risiko (Muhammad, 2017: 43-46) adalah:

a. Risiko pembiayaan (financing risk) yang disebabkan oleh nasabah wanprestasi atau default.

b. Risiko Pasar disebabkan oleh pergerakan nilai tukar jika pembiayaan atas dasar akad mudharabah atau musyarakah diberikan dalam valuta asing.

c. Risiko operasional yang disebabkan oleh internal fraud antara lain pencatatan yang tidak benar atas nilai posisi, penyogokan/penyuapan,

ketidaksesuaian pencatatan pajak (secara sengaja), kesalahan, manipulasi, dan mark up dalam 
Dani Ramdani, Prinsip Bagi Hasil Dalam Akad Mudharabah Dan Musyarakah Pada Bank Syari...

akuntansi/pencatatan maupun pelaporan.

\section{Metode Penghitungan Bagi Hasil}

Metode Penghitungan bagi hasil dibedakan menjadi tiga cara. Pertama, menggunakan metode prosfit and loss sharing, yaitu para pihak akan memperoleh bagian hasil sebesar nisbah yang telah disepakati dikalikan besarnya keuntungan (profit) yang diperoleh oleh pengusaha (mudharib), sedangkan apabila terjadi kerugian, ditanggung bersama sebanding dengan kontribusi masing-masing pihak. Kedua, menggunakan metode Profit Sharing, artinya para pihak mendapatkan bagian hasil sebesar nisbah dikalikan dengan perolehan keuntungan yang didapatkan oleh pengusaha (mudharib) sedangkan apabila terjadi kerugian secara financial akan ditanggung oleh pemilik dana (shahibul maal). Ketiga, menggunakan metode revenue sharing, yaitu para pihak mendapatkan bagian hasil sebesar nisbah dikalikan dengan besarnya pendapatan (revenue) yang diperoleh oleh pemilik usaha (mudharib) (Abdul Ghofur Anshori dalam Rachmadi Usman, 2009: 208).

\section{PENUTUP}

\section{Simpulan}

Bank Syariah adalah bank yang menjalankan kegiatan usahanya berdasarkan prinsip syariah. Prinsip syariah adalah aturan atau perjanjian, kesepakatan di antara para pihak bersumber syariat Hukum Islam.

Akad Mudharabah dan Musyarakah merupakan akad yang pelaksanaan berprinsip pada bagi hasil. Dengan demikian keuntungan yang diperoleh dalam kegiatan usahanya akan dibagi berdasarkan nisbah yang sebelumnya telah disepakati oleh para pihak. Sedangkan Kerugian yang terjadi ditanggung bersama-sama sesuai proposional modal yang dijadikan usahanya.

Metode yang digunakan untuk menghitung bagi hasil 
Dani Ramdani, Prinsip Bagi Hasil Dalam Akad Mudharabah Dan Musyarakah Pada Bank Syari...

dalam praktiknya menggunakan profit loss sharing untuk akad musyarakah, profit sharing untuk akad mudharabah dan revenue sharing untuk akad deposito mudharabah.

\section{Saran}

Beberapa hal penting yang harus diperhatikan sebagai upaya untuk perbaikan dan pengembangan perbankan syariah di Indonesia adalah regulasi yang ada pada saat ini perlu dioptamalisasikan termasuk lembaga-lembaga pelaksana dalam perbankan syariah harus mengembangkan sumber daya manusianya.

\section{DAFTAR PUSTAKA}

Adam, Panji., Fikih Muamalah Maliyah Konsep, Regulasi dan Implementasi, Bandung, Refika Aditama, 2017.

Andri, Soemitra., Bank dan Lembaga Keuangan Syariah, Edisi Kedua, Jakarta, Kencana, 2016.

Antonio, Muhammad Syafi'i., Bank Syariah dari Teori ke Praktek, Jakarta, Gema Insani, 2003.
Febriadi, Sandy Rizki, Akad Pengertian, Dasar Hukum, Rukun, Syarat Akad dan Macamnya,2018 dalam Pelatihan Dasar Perbankan Syariah yang dilaksanakan di Pascasarjana Universitas Islam Bandung, tanggal 1 April 2018.

Imaniyati, Neni Sri., Hukum Ekonomi dan Ekonomi Islam Dalam Perkembangan, Bandung, Mandar Maju, 2002.

$\begin{array}{lrr}\text { Regulasi } & & \text { Perkembangan } \\ \text { Syariah di } & \text { Perbankan } \\ \text { Peluang } & \text { dan } & \text { Tantangan, } \\ \text { 2005. } & & \end{array}$
2005.

Pencucian Uang
(Money Laundering)
dalam Persfektif Hukum
Perbankan dan Hukum
Islam, 2005.

, Urgensi Penguatan Hukum Baitul Maal Wat Tamwil (BMT) Dalam Persfektif Hukum Ekonomi, 2009. , Regulasi dan Eksistensi Koperasi Syariah di Bandung, 2009.

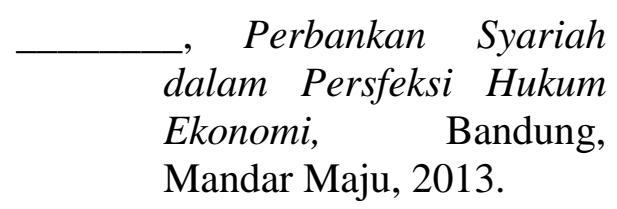


Dani Ramdani, Prinsip Bagi Hasil Dalam Akad Mudharabah Dan Musyarakah Pada Bank Syari...

Imaniyati, Neni Sri., dan Panji Adam, Pengantar Hukum Perbankan Indonesia, Bandung, Refika Aditama, 2016.

$\begin{array}{lr}\text { Dilengkapi Hukum } & \text { Bisnis } \\ \text { Kajian Hukum } & \text { Bisnis } \\ \text { Syariah, Bandung, Refika } & \\ \text { Aditama, 2017. } & \\ \text {, Menimbang Perbankan } \\ \text { Syariah Konsep, Regulasi } \\ \text { dan Praktik di Indonesia, } \\ \text { Bandung, r Refika } \\ \text { Aditama, 2017. }\end{array}$

Ikatan Bankir Indonesia, Memahami Bisnis Bank Syariah, Jakarta, Kompas Gramedia, 2018.

Mardani, Hukum Bisnis Indonesia, Jakarta, Kencana, 2014. Muhamad, Manajemen Dana Bank Syariah, Depok, Rajawali Press, 2017.

Usman, Rachmadi., Produk dan Akad Perbankan Syariah di Indonesia Implementasi dan Aspek Hukum, Jakarta, Citra Aditya Bakti, 2009.

Undang-Undang Nomor 21 Tahun 2008 tentang Perbankan Syariah.
Kompilasi Hukum Ekonomi Islam, Edisi Revisi, diterbitkan oleh Pusat Pengkajian Hukum Islam dan Masyarakat Madani (PPHIMM), 2017.

Fatwa Dewan Syariah Nasional Nomor: $\quad 07 / D S N-$ MUI/IV/2000 tentang Pembiayaan Mudharabah.

$\begin{array}{ccr}\text { Fatwa } & \text { Dewan Syariah } & \text { Nasional } \\ & \text { Nomor: } & \text { 08/DSN- } \\ & \text { MUI/IV/2000 } & \text { tentang } \\ & \text { Pembiayaan Musyarakah. }\end{array}$

